\title{
Bacterial Diversity in an Amazonian Mangrove Ecosystem
}

Leide MS Pureza (Corresponding author)

Laboratório de Polimorfismo de DNA, Universidade Federal do Pará Instituto de Ciências Biológicas, Postal Code 479, Pará State, Brazil

Tel: 55-91-3201-8416 E-mail: 1mspureza@gmail.com

\section{Diego A Graças}

Laboratório de Polimorfismo de DNA, Universidade Federal do Pará Instituto de Ciências Biológicas, Postal Code 479, Pará State, Brazil

\section{Evonnildo C Gonçalves}

Laboratório de Polimorfismo de DNA, Universidade Federal do Pará Instituto de Ciências Biológicas, Postal Code 479, Pará State, Brazil

\section{José AM Correa}

Laboratório de Polimorfismo de DNA, Universidade Federal do Pará Instituto de Geociências, Postal Code 479, Pará State, Brazil

\section{Dr. Artur Silva}

Laboratório de Polimorfismo de DNA, Universidade Federal do Pará Instituto de Ciências Biológicas, Postal Code 479, Pará State, Brazil

Dr. Maria PC Schneider

Laboratório de Polimorfismo de DNA, Universidade Federal do Pará Instituto de Ciências Biológicas, Postal Code 479, Pará State, Brazil Tel: 55-91-3201-8416 E-mail: paula@ufpa.br 
Received: October 5, 2012 Accepted: November 5, 2012 Published: January 1, 2013

doi:10.5296/ast.v1i1.2725 URL: http://dx.doi.org/10.5296/ast.v1i1.2725

\begin{abstract}
Mangroves form a transition zone among terrestrial, marine, and freshwater environments, and they host a striking diversity of macro- and microorganisms. In recent years, increasing anthropogenic impacts have caused widespread degradation of mangrove environments. To analyze the bacterial diversity of Salina Lake, an artificial body of water located in the mangroves of eastern Amazonia, total DNA was extracted from sediment and water samples that were collected from three sites (P1, P2, P3) located within the lake. The 16S rRNA gene was partially amplified, separated using the Denaturing High Performance Liquid Chromatography (DHPLC) method, and sequenced. The DHPLC profiles were quite distinct for the different aquatic and sedimentary bacterial communities. The most abundant groups $(>70 \%)$ at all sampled locations were Proteobacteria and unclassified bacteria, but other phyla were also identified, including Bacteroidetes, Cyanobacteria, Acidobacteria, Firmicutes, Actinobacteria, Chloroflexi, Siprochaetes and TM7. A total of 24, 15, and 23 OTUs (Operational Taxonomic Units) were observed in the water samples from P1, P2, and P3, respectively, whereas the sediment samples returned 29, 34, and 52 OTUs. This is the first analysis performed on the bacterial diversity of Salina Lake, which was created by the construction of a highway within a protected mangrove area.
\end{abstract}

Keywords: Diversity, Bacteria, Mangrove, Lake, 16S rRNA 


\section{Introduction}

Mangrove ecosystems cover vast areas of tropical and subtropical coastal zones, and their composition is influenced by tidal forces as well as high concentrations of dissolved nutrients and decomposing organic matter (Holguin et al., 2001; Holguin et al., 2006). Approximately one-third of the world's mangrove forests have disappeared over the past 50 years as a direct result of the expansion of human populations and increasing anthropogenic pressures on their natural resources (Duke et al., 2007; Alongi, 2002). Mangroves support the trophic network of coastal systems by tidal nutrients (Nedwell et al., 1994). The species composition of mangrove ecosystems is strongly influenced by physicochemical factors, particularly salinity (Lozupone \& Knight, 2007; Vieira et al., 2008; Silveira et al., 2011). Microorganisms play a fundamental role in ecosystem processes, such as the decomposition of organic matter (leaves and trees). These processes involve a complex bacterial community that produces nitrogen, phosphorus, and carbon, which combine to form the basis of the system's food chain (Holguin et al., 2001).

With the exception of a few recent studies, little is known about the diversity and ecological function of the bacterial communities found in mangrove ecosystems (Hewson \& Fuhrman, 2004; Zhang et al., 2008; Zhou et al., 2009; Gomes et al., 2010; Santos et al., 2011; Silveira et al., 2011). The present study was conducted to analyze the diversity and composition of the bacterial communities of a mangrove lake of Bragança-Pa in the eastern Amazon region. The analysis was performed using sequences of the bacterial 16S rRNA gene and the DHPLC method to infer the taxonomic relationships between the identified members of the community.

\subsection{Research Methods}

\subsubsection{Study Site and Sampling}

Lagoa Salina, or Salina Lake, is an artificial body of water that is located within the RESEX Marinha de Caeté-Taperaçú reserve (Figure 1). The lake is set within an extensive area of mangrove forest on the state's Atlantic coast. It has a circumference of $2.3 \mathrm{~km}$, a depth of 1.5 $\mathrm{m}$ and is not connected to any rivers or channels. The lake was formed during the construction of the PA-458 highway, which cut through $20 \mathrm{~km}$ of the mangrove forest and resulted in the damming of a number of tidal channels. These channels formed permanent lakes where trees died off and decomposed, thereby modifying the structure of the ecosystem and the composition of the local microbial community (Goch et al., 2005; Martins et al., 2006).

In the present study, $1 \mathrm{~L}$ samples of water and sediment were collected from Salina Lake on April 18th, 2009, at the following three sites (Figure 1): P1 (0053'42'S, 46 $40^{\prime}{ }^{\prime}$ ' $\left.\mathrm{W}\right), \mathrm{P} 2$

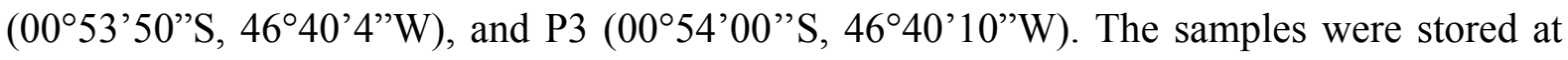
$-20^{\circ} \mathrm{C}$ until processing in the laboratory.

Water samples of $500 \mathrm{~mL}$ were collected from each site for chemical analysis $\left(\mathrm{Na}^{+}, \mathrm{Ca}^{2+}, \mathrm{K}^{+}\right.$, and $\mathrm{Mg}^{2+}$ ) using atomic absorption spectrometry, and physicochemical parameters, including $\mathrm{Cl}-, \mathrm{SO}_{4}{ }^{2-}$ by the titrimetric method, and $\mathrm{pH}$ by potentiometer. Salinity, electrical conductivity 
(EC), temperature, and concentration of total dissolved solids (TDS) were measured in situ with a probe during sample collection. Dissolved oxygen (DO) was measured according to the Winkler method (see Strickland \& Parsons, 1972). All analyses were performed at the hydrochemistry laboratory of the Geosciences Institute of the Federal University of Pará (UFPA).

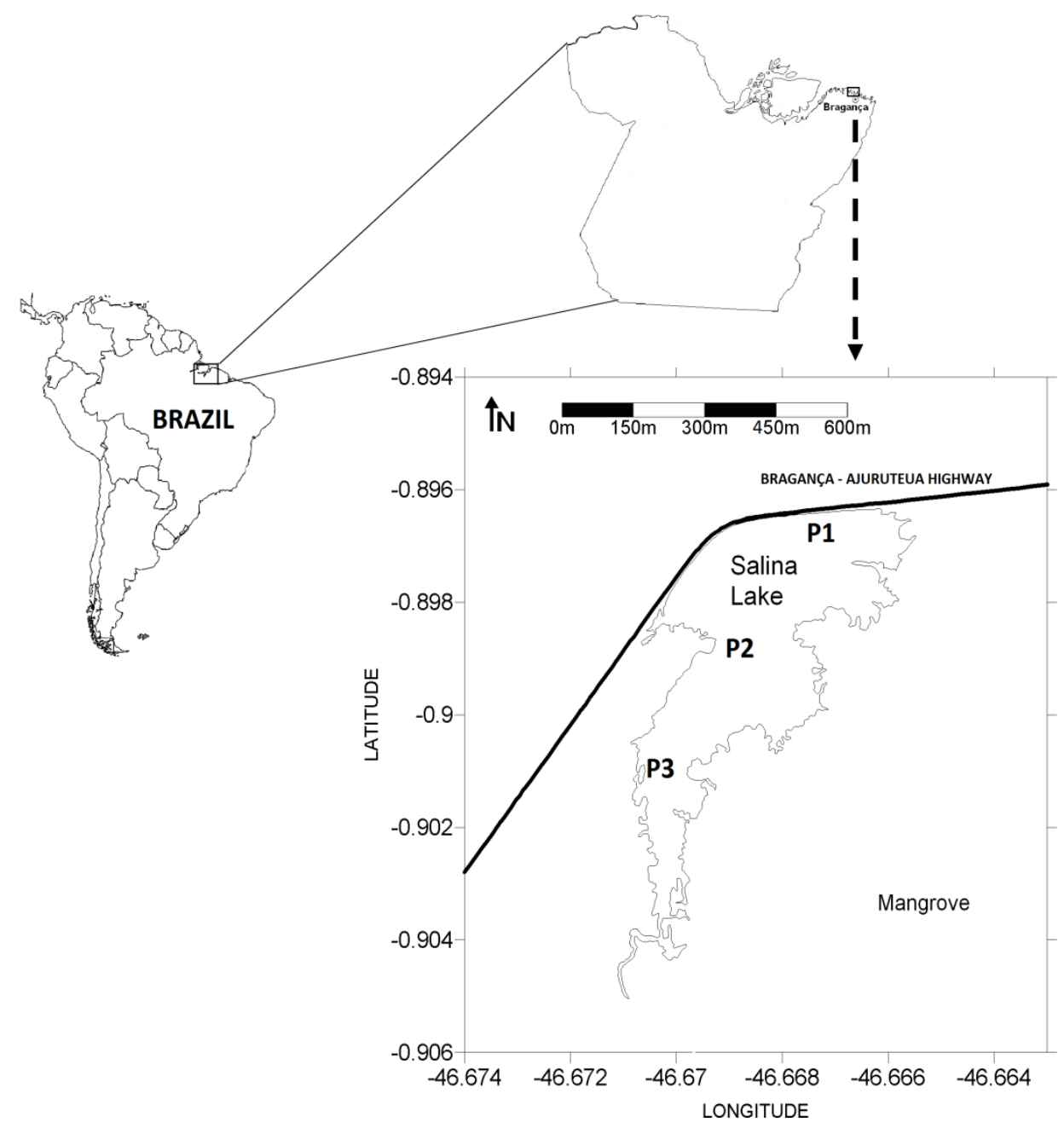

Figure 1. Location of Salina Lake in northeastern Pará

Description: Show the sampling sites P1, P2, and P3 within the area of the lake.

The sediment samples were collected with a metallic dredge and stored in $50 \mathrm{~mL}$ Falcon tubes. The water samples were filtered through a $0.8 \mu \mathrm{m}, 0.45 \mu \mathrm{m}$ and $0.22 \mu \mathrm{m}$ membranes, respectively (Whatman, Germany). The processed samples were stored in tubes with STE buffer (0.1 M NaCl, $10 \mathrm{mM}$ Tris-Cl, $1 \mathrm{mM}$ EDTA).

\subsubsection{Extraction of DNA}

The extraction and processing of total DNA were carried out in the tubes containing the 0.22 $\mu \mathrm{m}$ membranes that were used for sample collection. The samples were incubated with STE 
buffer under agitation. The cells were precipitated by sedimentation at $2,000 \mathrm{x} g$ for 10 minutes at room temperature. DNA was extracted from the precipitate that formed in the tube and from 0.2 grams of the sediment sample using an UltraCleanTM soil DNA extraction kit (MO BIO Laboratories, USA) according to the manufacturer's protocol. The extracted DNA was quantified by spectrophotometry, and its integrity was confirmed in a $1 \%$ agarose gel.

\subsubsection{Amplification of Fragments of the 16S rRNA Gene by PCR and DHPLC}

Fragments of the $16 \mathrm{~S}$ rRNA gene were amplified approximately $1,400 \mathrm{bps}$ in length by polymerase chain reaction (PCR) using the following specific primers for the bacterial $16 \mathrm{~S}$ rRNA gene: 16S-8F (AGA GTT TGA T(CT)(AC) TGG CTC AG), 16S-1407R (GAC GGG GGT G(AT)G T(AG)C AA) and 16S-1492R (CGG TTA CCT TGT TAC GAC TT).

The PCR contained 1X buffer, $2.0 \mathrm{mM} \mathrm{MgCl} 2,0.5 \mathrm{mM}$ dNTPs, $5 \mathrm{pmol} / \mu \mathrm{L}$ of each primer, and $1 \mathrm{U} / \mu \mathrm{L}$ of Taq DNA polymerase (Invitrogen, USA) in a final volume of $10 \mu \mathrm{L}$. Ten reactions at a final volume of $100 \mu \mathrm{L}$ for each sample were conducted to guarantee the amplification of rare DNA fragments. The cycling conditions for all the reactions were $95^{\circ} \mathrm{C}$ for 5 minutes, 35 cycles of 1 minute each at $95^{\circ} \mathrm{C}, 1$ minute at $60^{\circ} \mathrm{C}, 1$ minute at $72^{\circ} \mathrm{C}$, and a final extension of 5 minutes at $72^{\circ} \mathrm{C}$.

A second PCR using the DNA products generated by the first PCR was necessary for the insertion of the GC clamp into the amplicons. The reaction was performed using the oligonucleotides, DHPLC FP640 (CGC CCG CCG CGC GCG GCG GGC GGG GCG GGG GCA CGG GGG GCC TAC GGG AGG) and DHPLC 534R (ATT ACC GCG GCT GCT GCT GG) (Muyzer et al., 1993), which amplified a fragment of approximately 300 base pairs in length corresponding to the variable V3 region of the $16 \mathrm{~S}$ rRNA bacterial gene. The cycling conditions for all the reactions were $95^{\circ} \mathrm{C}$ for 5 minutes followed by 35 cycles of 1 minute each at $95^{\circ} \mathrm{C}, 40$ seconds at $62^{\circ} \mathrm{C}$, and 32 seconds at $72^{\circ} \mathrm{C}$ with a final extension of 10 minutes at $72^{\circ} \mathrm{C}$.

After the second amplification, the amplicons were processed using a Transgenomic WAVE system (Xiao \& Oefner, 2001), at a flow rate of $0.9 \mathrm{~mL} / \mathrm{minute}$. Samples were injected into the dHPLC system using a two-eluant buffer system: Buffer 'A' consisted of $100 \mathrm{mM}$ triethylammonium acetate (TEAA), $\mathrm{pH} 7.0$ and $0,025 \%$ acetonitrile (Transgenomic, USA) in aqueous solution, and Buffer ' $B$ ' consisted of $100 \mathrm{mM}$ triethylammonium acetate, $\mathrm{pH} 7.0$ with $25 \%$ (vol/vol) acetonitrile (Transgenomic, USA) and $100 \mathrm{mM}$ EDTA. For the column wash, an aqueous solution with $75 \%(\mathrm{vol} / \mathrm{vol})$ acetonitrile was used. The detection of the fragments was carried out through fluorescent dyes. The non redundant peaks produced for all of the samples were collected and a new PCR was then performed using the same conditions that were used in the second reaction.

The fragments were first separated, then purified with a GeneJETTM purification kit (Thermo Scientific, USA) and finally cloned using the TOPO TA cloning kit (Invitrogen, USA). A total of 15 libraries were built and twenty-four recombinant clones were selected randomly from each peak within each library for sequencing in an automatic sequencer (3730 DNA Analyzer, Life Technology, USA). 


\subsubsection{Analysis of Diversity and Phylogenetic Relationships}

The sequences were edited with BioEdit v7.0.9 software. The sequences were checked for the presence of chimeric sequences using the Quimera check tool and then compared with the sequences in the Ribosomal Database Project (RDP) (Cole et al., 2009) using the Classifier and SeqMatch tools and GenBank ${ }^{\circledR}$ to determine the closest sequences and their taxonomies. The distance matrix was then generated using the PHYLIP package; the rarefaction curve was constructed, and the Shannon diversity index and Chao species richness estimator were calculated using the Mothur 1.20.3 program (Schloss \& Handelsman, 2005). The non-parametric estimator of coverage $(C)$ was calculated using the formula, $C=1-n 1 / N$, where $\mathrm{n} 1=$ the number of phylotypes that appear only once in the library and $\mathrm{N}=$ the size of the library. The Mothur program was also used to compare the community structure using $\int$ -Libshuff.

Finally, a dendrogram was constructed from the unique OTUs with the MEGA4 software (Tamura et al., 2007) using the Neighbor-Joining method. Evolutionary distances were calculated using the Jukes-Cantor model (Saitou \& Nei, 1987).

\section{Results}

\subsection{Analysis of the Physicochemical Parameters of the Water}

The physicochemical parameters of the water at each sampling site are shown in Table 1 . The temperature of the water varied between $26^{\circ} \mathrm{C}$ and $27^{\circ} \mathrm{C}$. The low salinity and reduced concentrations of cations $\left(\mathrm{Na}^{+}, \mathrm{Ca}^{2+}, \mathrm{K}^{+}, \mathrm{Mg}^{2+}, \mathrm{SO}_{4}{ }^{2-}\right)$, total dissolved solids, and $\mathrm{Cl}-$ recorded at all the sites can be attributed to the high levels of precipitation in the study area. At all sites, the concentration of dissolved oxygen varied according to the depth of the water (unpublished data), which may be related to the variation in the redox potential at the different sites.

Table 1. Physicochemical parameters of water

\begin{tabular}{ccccccccccccc}
\hline Sample & $\mathbf{T}\left({ }^{\circ} \mathbf{C}\right)$ & Sal & $\mathbf{p H}$ & $\mathbf{O}_{\mathbf{2}}$ & $\mathbf{C o n d}\left(\boldsymbol{\mu S} \cdot \mathbf{c m}^{-1}\right)$ & $\mathbf{S D T}$ & $\mathbf{C l}^{-}$ & $\mathbf{S O}_{\mathbf{4}}{ }^{2-}$ & $\mathbf{N a}^{+}$ & $\mathbf{K}^{+}$ & $\mathbf{C a}^{\mathbf{2 +}}$ & $\mathbf{M g}^{\mathbf{2 +}}$ \\
\hline P1 & 26.5 & 0.4 & 4.6 & 4.3 & 844 & 406 & 219 & 42 & 85 & 5.8 & 2.8 & 8.6 \\
P2 & 27.1 & 0.4 & 5.1 & 6.5 & 864 & 414 & 219 & 42 & 87 & 5.7 & 0.2 & 1.3 \\
P3 & 26.6 & 0.3 & 4.0 & 3.1 & 682 & 326 & 173 & 34 & 68 & 4.3 & 1.4 & 6.2
\end{tabular}

Description: Physicochemical properties of the water samples collected at sites P1, P2, and P3 in Salina Lake, Bragança, Pará. $\left(\mathrm{O}_{2}\right.$, TDS and cations/anions values are in $\left.\mathrm{mgL}^{-1}\right)$.

The water was relatively acidic, with $\mathrm{pH}$ values between 4.0 and 5.1 (which are similar to those of rainwater), indicating that the lake is supplied primarily by the year-round precipitation that is typical of the region. Electrical conductivity was relatively uniform (Table 1) with the highest and lowest values recorded at sites P3 and P1, respectively. These sites are located near the outermost extremes of the lake (Figure 1). These values are considerably higher than $100 \mu \mathrm{S} \cdot \mathrm{cm}-1$ and are influenced by the high levels of dissolved 
solids, which are themselves indicative of corrosive waters and an impacted environment.

\subsection{Profile of the Communities, Sequencing, Editing, and Taxonomic Analyses}

The graphs generated by DHPLC for the aquatic communities obtained from sites P1, P2, and P3 presented 4, 6, and 5 peaks, respectively, with the best resolution observed at a temperature of $64.5^{\circ} \mathrm{C}$ (Figure 2a-c). For the sedimentary communities, the plots with the best resolution and separation for sites $\mathrm{P} 1$ and $\mathrm{P} 2$ each presented 6 peaks at $64.5^{\circ} \mathrm{C}$ (Figure $2 \mathrm{~d}-\mathrm{e}$ ), and site $\mathrm{P} 3$ presented 8 peaks at $65^{\circ} \mathrm{C}$ (Figure 2f). The minor peaks were not collected because their lower resolution indicates that they might show the same microbial composition as the adjacent peaks (Figure 2). The distinct profiles obtained from the different samples appear to reflect the considerable diversity of the local bacterial communities to compare with each other.

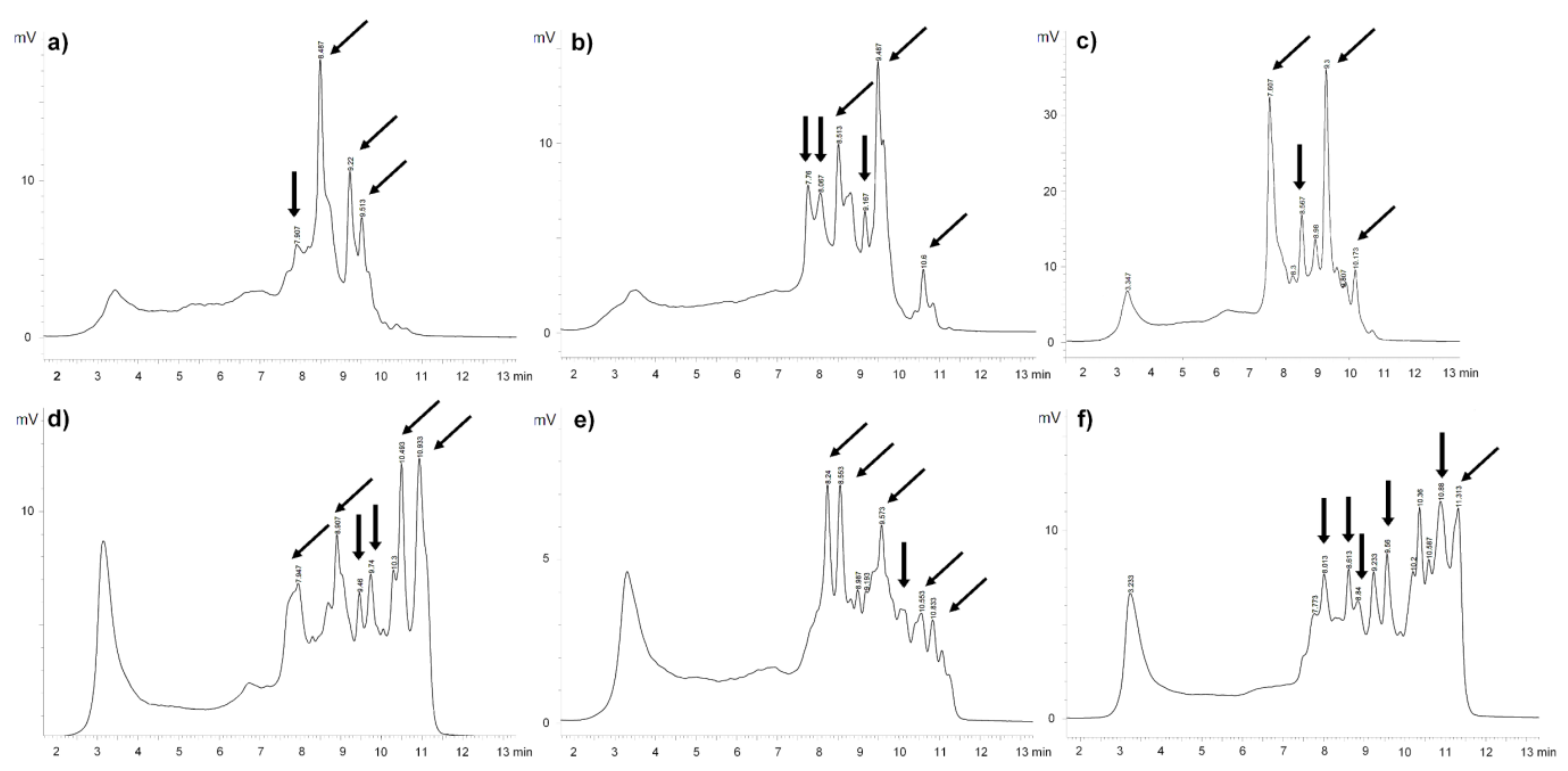

Figure 2. DHPLC analysis of the amplified fragments of the 16S rRNA gene

Description: The profiles of the communities contained in the water (P1 - a, P2 - b, P3 - c) and sediment samples $(\mathrm{P} 1-\mathrm{d}, \mathrm{P} 2-\mathrm{e}, \mathrm{P} 3-\mathrm{f})$, are characterized by peaks representing specific retention times. The arrows indicate the peaks collected for the investigation of the composition of the microbial population.

The processing of the 284 clones from the collected peaks resulted in 269 sequences that were valid for analysis (accession numbers HE648576-HE648837). Each sequence was approximately 200 bps long. Comparison with the RDP database indicates that theses belong to the Proteobacteria, Firmicutes, Bacterioidetes, Acidobacteria, Spirochaetes, Actinobacteria, Chloroflexi, Cyanobacteria, and TM7 phyla; unclassified bacteria were also obtained (Figure 3). The most abundant phylum in the lake water was Proteobacteria (53\%), whereas in the sediments, the unclassified bacteria predominated $(48 \%)$. At site P1, the unclassified bacteria were relatively abundant in both the water and sediment samples, whereas at site P2, Proteobacteria predominated in both the water and sediment samples. 


\section{$\triangle$ Macrothink}

Proteobacteria also predominated in the sediment sample from site P3. However, in the water sample from P3, unclassified bacteria were the most abundant (Figure 3).

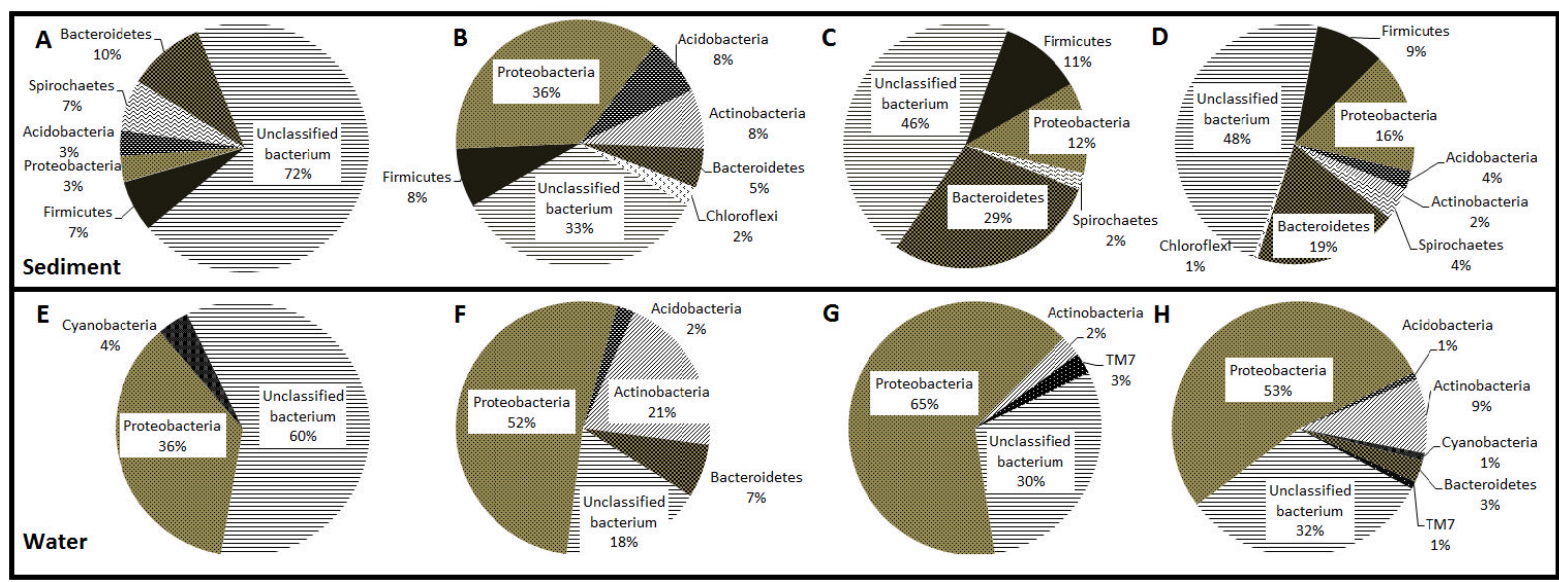

Figure 3. Relative abundance (\%) and taxa observed at Salina Lake

Description: This is based on the criterion of $80 \%$ similarity with the sequences available in the RDP database, for the three sampling sites, P1 (A, E), P2 (B, F), P3 (C, G), and the total sample (D, H). Sediment samples are shown in the top row, water samples in the bottom row.

\subsection{Statistical Analyses}

The libraries for the sediment samples from sites P1, P2, and P3 contain 29, 34, and 52 unique operational taxonomic units (OTUs), respectively, whereas those for the water samples contain 24, 15, and 23 OTUs, respectively (with a difference of 0.03) (Figure 4). An analysis of the Shannon's diversity index and the Chao species richness estimator indicated that there was greater diversity in the sediment samples when compared with the samples obtained from the water. The highest values for the sediment were recorded at site P3, and the highest values for the water were recorded at P1. The number of rare phylotypes in both the water and sediment samples may account for this variation, which indicates that the diversity of these communities is so high that the number of OTUs sampled was insufficient to represent the true diversity of species at site P1. This conclusion is supported by the values obtained using the $\mathrm{C}$ coverage estimator (Table 2).

Table 2. Diversity indices for bacterial OTUs

\begin{tabular}{|c|c|c|c|c|c|c|c|c|}
\hline \multirow{2}{*}{ Indices } & \multicolumn{4}{|c|}{ Sediment Sample } & \multicolumn{4}{|c|}{ Water Sample } \\
\hline & P1 & P2 & P3 & Total & P1 & $\mathbf{P 2}$ & $\mathbf{P 3}$ & Total \\
\hline Shannon $^{a}$ & 33.7 & 3.2 & 36.0 & 4.5 & 3.2 & 2.4 & 2.8 & 3.9 \\
\hline Chao & 435.0 & 102.0 & $1,125.0$ & 367.9 & 300.0 & 22.0 & 108.5 & 331.2 \\
\hline Coverage & 0.0 & 0.2 & 0.6 & 0.4 & 0.0 & 0.8 & 0.5 & 0.5 \\
\hline
\end{tabular}

a. Non-parametric estimator of Shannon diversity indice.

Description: Shannon (H') and Chao indices with a difference of 3\% and coverage for the sediment and water samples from each site in Salina Lake. 

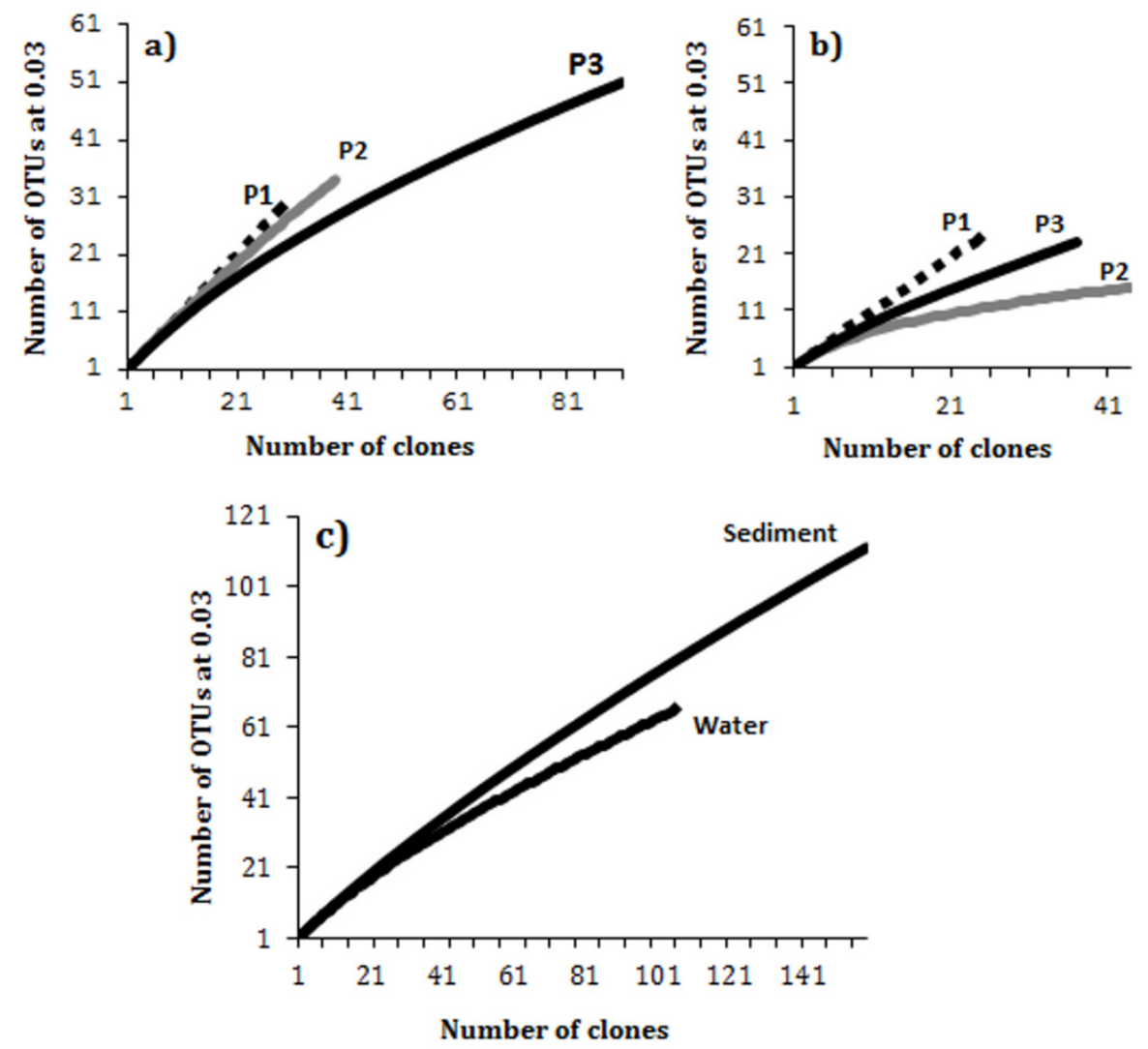

Figure 4. Rarefaction curve for the unique OTUs

Description: The unique OTUs found in the sediment (a) and water (b) of each sampling site, and the aquatic and sedimentary communities as a whole (c).

The $\mathrm{C}$ estimator indicates that the sediment and water communities at sites $\mathrm{P} 2$ and $\mathrm{P} 3$ had a coverage of $20 \%, 80 \%, 60 \%$, and $50 \%$ (Table 2). Total coverage was $50 \%$ for the water samples and $40 \%$ for the sediment samples

The dendrograms indicate the degree of relationship among the communities at the different sampling sites (Figures 5 and 6). The Proteobacteria, Bacteroidetes, Firmicutes, Chloroflexi, and Spirochaetes phyla all formed separate clades with bootstrap values of over 80 . The most abundant phylum in the aquatic community was the Proteobacteria, which formed a large clade that was well separated from the other phyla with high bootstrap values, except for two sequences that were distinct from both the main group and each other. These two sequences were HE648679, which formed a well-defined clade (bootstrap =91) with a sequence from the database (Figure 5), and HE648617, which formed a clade with Bacteriovorax sp. (bootstrap = 96). Two unclassified cyanobacterial clones (HE648587 and HE648629) were also grouped separately with a high bootstrap value (96). These two clones are from different sampling sites; HE648587 was from P1, which is closer to the highway and suffers greater anthropogenic impact, and HE648629 was from site P2, which is in the middle of the lake. 


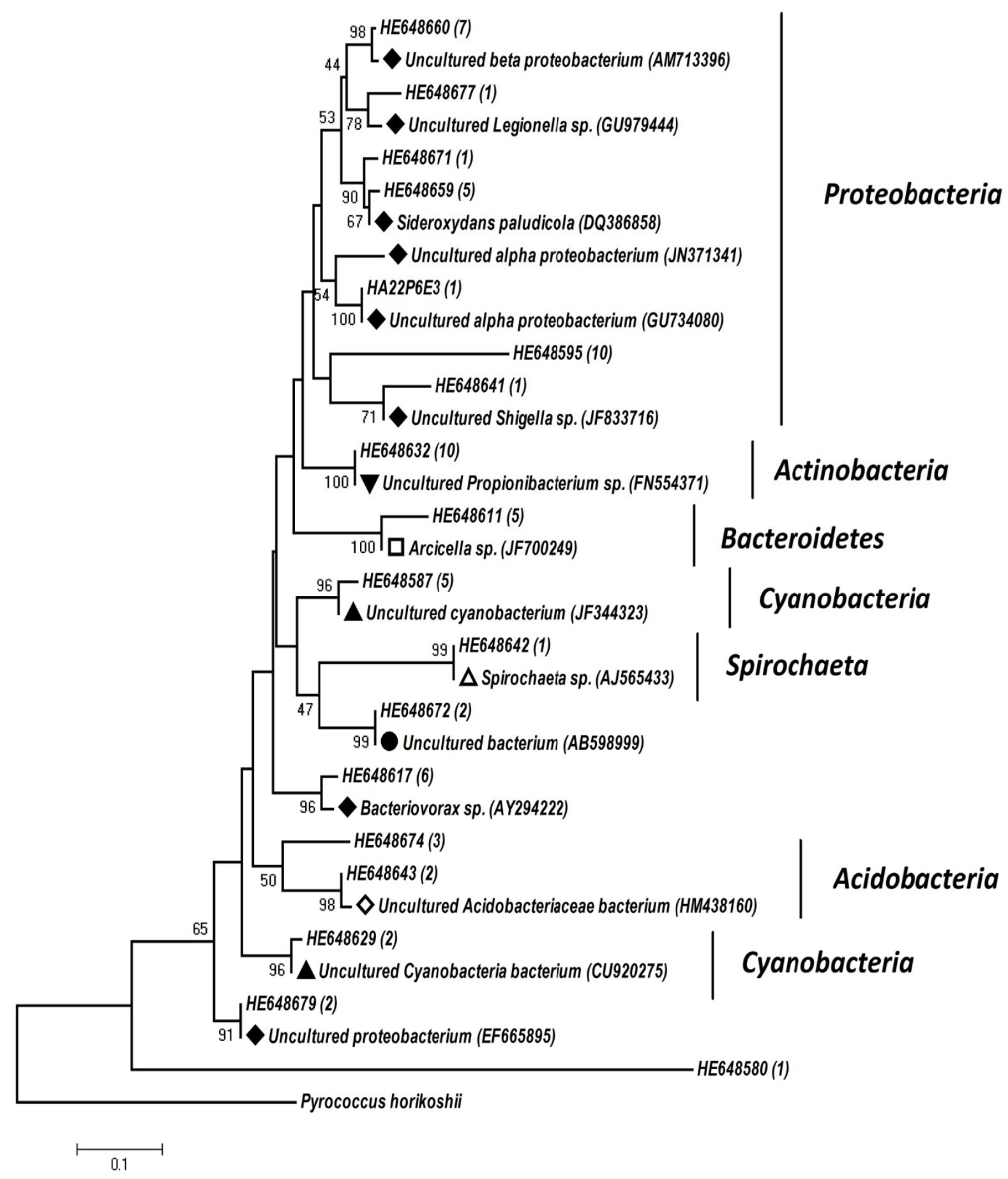

Figure 5. Dendrogram based on the sequences of the 16S rRNA gene for the bacterial phyla found in the water samples collected from Salina Lake

Description: Proteobacteria $(\bullet)$, Chloroflexi $(\bigcirc)$, Cyanobacteria $(\boldsymbol{\Delta})$, Actinobacteria $(\boldsymbol{\nabla})$, Bacteroidetes $(\square)$, Spirochaetes $(\Delta)$, Acidobacteria $(\diamond)$, Firmicutes $(\mathbf{\square})$, unclassified bacteria $(\boldsymbol{O})$. The numbers in brackets beside the name of each sequence indicate the number of clones produced for the respective sequence. 


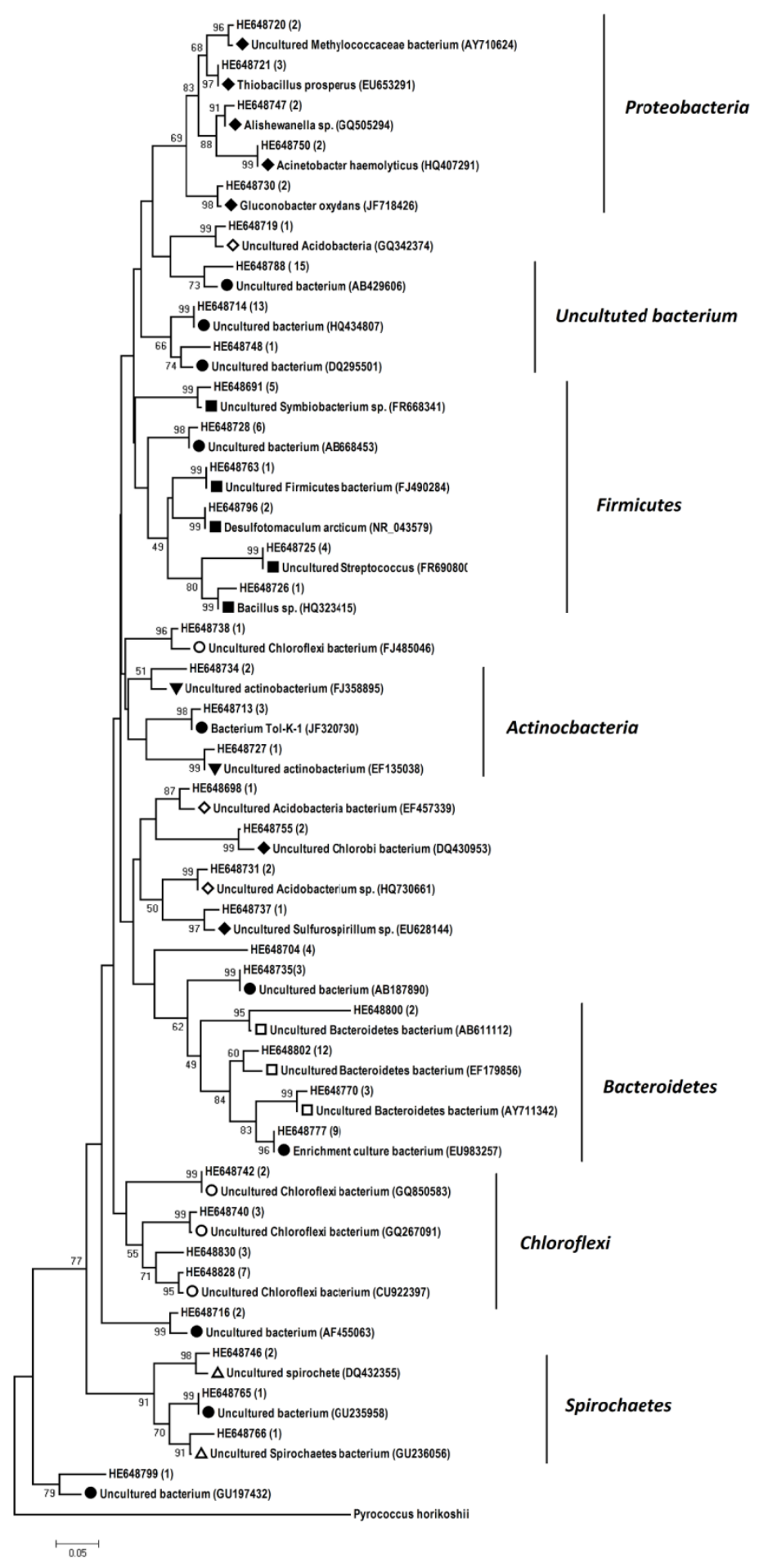

Figure 6. Dendrogram based on the sequences of the 16S rRNA gene for the bacterial phyla found in the sediment samples collected from Salina Lake

Description: Proteobacteria $(\diamond)$, Chloroflexi $(\bigcirc)$, Cyanobacteria $(\mathbf{\Delta})$, Actinobacteria $(\boldsymbol{\nabla})$, Bacteroidetes $(\square)$, Spirochaetes $(\Delta)$, Acidobacteria $(\diamond)$, Firmicutes $(\boldsymbol{\square})$, unclassified bacteria $(\boldsymbol{O})$. The numbers in brackets beside the name of each sequence indicate the number of clones produced for the respective sequence. 
The $\int$-Libshuff analysis indicated that the structure of the communities from each sampling site (water and sediment) are statistically different from each other $(\mathrm{p}<0.001)$, suggesting that each community may be considered to be a distinct ecosystem (Appendix 2).

\section{Discussion}

The profiles identified in the present study were similar to those reported for complex environmental communities (Wagner et al., 2009; Barlaan et al., 2005), although the chromatogram patterns obtained in the present study showed peaks with better resolution and separation (Figure 2). By comparing the number of peaks in the DHPLC chromatograms with the number of groups observed in the taxonomic graphs there is much similarity (Figures 1 and 2). The represented bacterial groups are Proteobacteria, Bacterioidetes, Actinobacteria, Acidobacteria, Firmicutes, Chloroflexi, Spirochaetes, Cyanobacteria, and unclassified bacteria (Figures 5 and 6). These phyla are relatively common in the mangrove systems of southeastern Brazil (Almeida et al., 2009; Gomes et al., 2010; Santos et al., 2011; Silveira et al., 2011) and in other tropical and subtropical countries, such as India, China, Australia, and the United States (Zhang et al., 2008; Zhou et al., 2009), both aquatic and sedimentary communities (Clementino et al., 2008; Vieira et al., 2008).

The distribution of the different bacterial groups within the area of the lake reflect the influence of chemical, physical, and geographical factors, such as $\mathrm{pH}$, temperature, salinity, redox potential, and competition, that favor their development (Lozupone \& Knight, 2007; Dimitriu et al., 2008; Caporaso et al., 2011). The local climate is divided into a rainy season between January and July and a dry season between August and December. The principal variations in abiotic conditions are caused by equinoctial tides, which may reach $6 \mathrm{~m}$ and cause strong two-way currents and seasonal fluctuations in river discharge. These phenomena exert a considerable influence on the species composition of the local communities (Cohen et al., 1999; Lara \& Dittmar 1999). These characteristics represent the occurrence of ecological succession, given that this environment is undergoing restructuring after clearing the lake area and decomposition of tree species.

The represented bacterial groups are involved in a number of different biogeochemical cycles and the decomposition of mangrove vegetation. The organisms function in the liberation of $\mathrm{CO} 2$, phosphorus and nitrogen, which are the principal elements in the trophic network (Holguin et al., 2001; Hewson \& Fuhrman, 2004; Zhang et al., 2008; Ghosh et al., 2010). For example, Desulfotomaculum arcticum (recorded at P3), which survives at high temperatures and is involved in the sulfur cycle. This species is a reducer of sulfates, and like other species of the genus, it liberates hydrogen sulfate into the environment, a feature that is characteristic of mangrove systems (Vandieken et al., 2006).

Several classes from the Proteobacteria phylum, including the Betaproteobacteria, Deltaproteobacteria, and Gamaproteobacteria classes, were the most abundant organisms found in the aquatic community of the lake (at sites P2 and P3). These classes are involved in the cycling of carbon, nitrogen, and sulfur in the ecosystem and include Desulforhopalus singaporensis, a sulfur-reducing deltaproteobacterium that was found at site P3, which is close to the undisturbed mangrove. Other important detected organisms include unclassified 
cyanobacteria, which are involved in the consumption of nitrogen for the production of oxygen, Bacteriovorax sp. and an unclassified betaproteobacterium of the order, Methylophilales. Each of the latter organisms is found in areas with salinity concentrations above $0.5 \%$ (Baer et al., 2004), which is similar to the concentration recorded in the present study (Appendix 1). Representatives of the Acidobacteria were also present, although most of the recognized taxa are still unclassified. The ecology of this phylum is not well understood, although representatives can be found in a range of environments. Organisms from subdivision I, known as true acidophiles, grow at a $\mathrm{pH}$ of between 3.5 and 4.5, a range that corresponds to the values recorded at Salina Lake (Table 1) (Davis et al., 2011).

Propionibacterium was found at P2. This genus of pathogenic bacteria causes diseases, such as acne, in humans. The bacterial groups present in the sedimentary community, including the Alphaproteobacteria, Betaproteobacteria, and sulfur-reducing groups, such as Desulfotomaculum arcticum and Sulfurospirillum, are commonly found in estuarine and marine environments (Dimitriu et al., 2008). These organisms play an important role in the biogeochemical cycle of the ecosystem (Jennerjahn \& Ittekko 2002). Bacterial groups from the Spirochaetes phylum, which cause a number of diseases in humans, were also found in the present study. A representative of the TM7 phylum was found in the water sample from site P3 (Appendix 1).

The composition of the sedimentary community was quite distinct from that of the aquatic group (48\%). This indicates that the diversity of species found in the sediment is much higher than that present in the aquatic community. This result was also verified by Shannon and Chao diversity indice and the rarefaction curves. Similar results have been observed in a number of previous studies (Kemp \& Aller 2004; Lozupone \& Knight, 2007; Caporaso et al., 2011; Graças et al., 2011).

The analysis of community structure ( $\int$-Libshuff) indicated that both the sedimentary and aquatic communities were the most distinct at site P2. These findings may be due to the presence or absence of certain phylotypes in these communities (Schloss \& Handelsman 2004), such as the presence of one more phylum in the sedimentary community at P2 than P1 (Appendix 2).

The high diversity at P2 and P3 site, the low coverage observed at site P1 and the evidence of bacterial groups derived from external environments into the lake by tides corroborate the occurrence of ecological succession, with a dynamic recruitment and domain groups regarding the frequency of phyla Proteobacteria, Firmicutes, Bacterioidetes, Actinobactérias, Acidobacteria, Chloroflexi, Espiroquetas in all sampling points of the Saline Lake (Figure 3). It also indicated a clear shift in the composition of community structure among aquatic environments, sediments and location of each community.

\section{Conclusions}

The present study provided a preliminary description of the composition of bacterial diversity in the aquatic and sedimentary communities at the Salina Lake of Bragança-Pa, northeast Amazonia. Composition differences of these communities and their probable role in the 
ecosystem indicate the occurrence of ecological succession. The difference in the abundance of phyla, species of different ecological groups and unclassified bacteria indicates the differentiation of successional stages. Proteobacteria was the most abundant phylum in aquatic and sediment communities and was recognized as opportunistic and pioneer. However, more seasonal studies will be necessary to understand the true diversity of this biota and its role within the local environment.

\section{Acknowledgement}

This study is part of the PRONEX/CNPq project, "A microbiological observatory of the Brazilian Amazon: a study of microbial diversity and ecology using a metagenomic approach". We are grateful to the Pará State Scientific Research Foundation (FAPESPA).

\section{References}

Almeida, W. I., Vieira, R. P., Cardoso, A. M., Silveira, C. B., Costa, R. G., Gonzalez, A. M. et al. (2009). Archaeal and bacterial communities of heavy metal contaminated acidic waters from zinc mine residues in Sepetiba Bay. Extremophiles, 13, 263-271. http://dx.doi.org/10.1007/s00792-008-0214-2

Alongi, D. M. (2002). Present state and future of the world's mangrove forests. Environmental Conservation, 29, 331-349. http://dx.doi.org/10.1017/S0376892902000231

Baer, M. L., Ravel, J., Piñeiro, S. A., Guether-Borg, D., \& Williams, H. N. (2004). Reclassification of salt-water Bdellovibrio sp. as Bacteriovorax marinus sp. nov. and Bacteriovorax litoralis sp. nov. International Journal of Systematic and Evolutionary Microbiology, 54, 1011-1016. http://dx.doi.org/10.1099/ijs.0.02458-0

Barlaan, E. A., Sugimori, M., Furukawa, S., \& Takeuchi, K. (2005). Profiling and monitoring of microbial populations by denaturing high-performance liquid chromatography. $J$. Microbiol. Methods, 61, 399-412. http://dx.doi.org/10.1016/j.mimet.2005.01.002

Caporaso, J. G., Lauberb, C. L., Waltersc, W. A., Berg-lyonsb, D., Lozupone, C. A., Turnbaughd, P. J., et al. (2011). Global patterns of 16S rRNA diversity at a depth of millions of sequences per sample. PNAS, 108, 4516-4522. http://dx.doi.org/10.1073/pnas.1000080107

Clementino, M. M., Vieira, R. P., Cardoso, A. M., Nascimento, A. P. A., Silveira, C. B., Riva, T. C., et al. (2008). Prokaryotic diversity in one of the largest hypersaline coastal lagoons in the world. Extremophiles, 12, 565-604. http://dx.doi.org/10.1007/s00792-008-0162-x

Cohen, M. C. L., Lara, R. J., Ramos, J. F. F., \& Dittmar, T. (1999). Factors influencing the variability of $\mathrm{Mg}, \mathrm{Ca}$ and $\mathrm{K}$ in waters of a mangrove creek in Bragança, North Brazil. Mangroves and Salt Marshes, 3, 9-15. http://dx.doi.org/10.1023/A:1009923513091

Cole, J. R., Wang, Q., Cardenas, E., Fish, J., Chai, B., Farris, R. J., et al. (2009). The Ribosomal Database Project: improved alignments and new tools for rRNA analysis. Nucleic Acids Research, 37, 141-145. http://dx.doi.org/10.1093/nar/gkn879

Davis, K. E. R., Sangwan, P., \& Janssen, P. H. (2011). Acidobacteria, Rubrobacteridae and Chloroflexi are abundant among very slow-growing and mini-colony-forming soil bacteria. Environmental Microbiology, 798-805. http://dx.doi.org/10.1111/j.1462-2920.2010.02384.x 
Dimitriu, P. A., Pinkart, H. C., Peyton, B. M., \& Mormile, M. R. (2008). Spatial and Temporal Patterns in the Microbial Diversity of a Meromictic Soda Lake in Washington State. Applied and Environmental Microbiology, 74, 4877-4888. http://dx.doi.org/10.1128/AEM.00455-08

Duke, N. C., Meynecke, J. O., Dittmann, S., Ellison, A. M., Anger, K., Berger, U., et al. (2007). A world without mangroves? Science, 317, 41-42. http://dx.doi.org/10.1126/science.317.5834.41b

Ghosh, A., Dey, N., Bera, A., Tiwari, A., Sathyaniranjan, K. B., Chakrabarti, K., \& Chattopadhyay, D. (2010). Culture independent molecular analysis of bacterial communities in the mangrove sediment of Sundarban, India. Saline Systems, 6, 1-11. http://dx.doi.org/10.1186/1746-1448-6-1

Goch, Y. G. F., Krumme, U., Saint-paul, U., \& Zuanon, J. A. S. (2005). Seasonal and diurnal changes in the fish fauna composition of a mangrove lake in the Caeté estuary. Amazoniana, $18,299-315$.

Gomes, N. C. M., Flocco, C. G., Costa, R., Junca, H., Vilchez, R., Pieper, D. H., et al. (2010). Mangrove microniches determine the structural and functional diversity of enriched petroleum hydrocarbon-degrading consortia. FEMS Microbiology Ecology, 74, 276-290. http://dx.doi.org/10.1111/j.1574-6941.2010.00962.x

Graças, D. A., Miranda, P. R., Baraúna, R. A., McCulloch, J. A., Ghilardi Jr, R., Schneider, M. P. C., \& Silva, A. (2011). Microbial Diversity of an Anoxic Zone of a Hydroelectric Power Station Reservoir in Brazilian Amazonia. Microbiology Ecology, 62, 853-861. http://dx.doi.org/10.1007/s00248-011-9906-8

Hewson, I., \& Fuhrman, J. A. (2004). Richness and Diversity of Bacterioplankton Species along an Estuarine Gradient in Moreton Bay. Australia Applied and Environmental Microbiology, 70, 3425-343. http://dx.doi.org/10.1128/AEM.70.6.3425-3433.2004

Holguin, G., Gonzalez-Zamorano, P., de-Bashan, L. E., Mendoza, R., Amador, E., \& Bashan, Y. (2006). Mangrove health in an arid environment encroached by urban development - a case study. Science of the Total Environment, 363, 260-274. http://dx.doi.org/10.1016/j.scitotenv.2005.05.026

Holguin, G., Vazquez, P., \& Bashan, Y. (2001). The role of sediment microorganisms in the productivity, conservation, and rehabilitation of mangrove ecosystems, an overview. Biology and Fertility of Soils, 33, 265-278. http://dx.doi.org/10.1007/s003740000319

Jennerjahn, T. C., \& Ittekko, V. (2002). Relevance of mangroves for the production and deposition of organic matter along tropical continental margins. Naturwissenschaften, 89, 23-30. http://dx.doi.org/10.1007/s00114-001-0283-x

Kemp, P. F., \& Aller, J. Y. (2004). Bacterial diversity in aquatic and other environments: what 16S rDNA libraries can tell us. FEMS Microbiology Ecology, 47, 161-177. http://dx.doi.org/10.1016/S0168-6496(03)00257-5

Lara, R. J., \& Dittmar, T. (1999). Nutrient dynamics in a mangrove creek (North Brazil) during the dry season. Mangroves and Salt Marshes, 3, 185-195. http://dx.doi.org/10.1023/A:1009903824243

Lozupone, C. A., \& Knight, R. (2007). Global patterns in bacterial diversity. PNAS, 104, 
11436-11440. http://dx.doi.org/10.1073/pnas.0611525104

Martins, A. A. V., Costa, R. A. M., \& Pereira, L. C. C. (2006). Distribuição espaço-temporal da comunidade zooplanctônica de uma lagoa costeira artificial na região amazônica, Bragança, Pará, Brasil. Boletim do Museu Paraense Emilio Goeldi Ciências Naturais, 1, 103-111.

Muyzer, G., De Waal, E. C., \& Uitierlinden, A. G. (1993). Profiling of Complex Microbial Populations by Denaturing Gradient Gel Electrophoresis Analysis of Polymerase Chain Reaction-Amplified Genes Coding for 16S rRNA. Applied and Environmental Microbiology, 59, 695-700.

Nedwell, D. B., Blackburn, T. H., \& Wiebe, W. J. (1994). Dynamic nature of the turnover of organic carbon, nitrogen and sulphur in the sediments of a Jamaican mangrove forest. Marine Ecology Progress Series, 110, 223-231.

Saitou, N., \& Nei, M. (1987). The Neighbor-joining Method: A New Method for Reconstructing Phylogenetic Trees. Molecular Biology and Evolution, 4, 406-425.

Santos, H. F., Cury, J. C., Carmo, F. L., Santos, A. L., Tiedje, J., \& van Elsas, J. D. (2011). Mangrove Bacterial Diversity and the Impact of Oil Contamination Revealed by Pyrosequencing: Bacterial Proxies for Oil Pollution. PLoS ONE, 6, 1-8. http://dx.doi.org/10.1371/journal.pone.0016943

Schloss, P. D., \& Handelsman, J. (2004). Integration of Microbial Ecology and Statistics: a Test To Compare Gene Libraries. Applied and Environmental Microbiology, 70, 5485-5492. http://dx.doi.org/10.1128/AEM.70.9.5485-5492.2004

Schloss, P. D., \& Handelsman, J. (2005). Introducing DOTUR, a Computer Program for Defining Operational Taxonomic Units and Estimating Species Richness. Applied and Environmental Microbiology, $\quad 71, \quad 1501-1506$. http://dx.doi.org/10.1128/AEM.71.3.1501-1506.2005

Silveira, C. B., Vieira, R. P., Cardoso, A. M., Paranhos, R., Albano, R. M., \& Martins, O. B. (2011). Influence of Salinity on Bacterioplankton Communities from the Brazilian Rain Forest to the Coastal Atlantic Ocean. PLoS One, 6, 1-9. http://dx.doi.org/10.1371/journal.pone.0017789

Strickland, J. D. H., \& Parsons, T. R. (1972). A practical handbook of sea water analysis, 167th edn. Canada, Ottawa.

Tamura, K., Dudley, J., Nei, M., \& Kumar, S. (2007). MEGA4: Molecular Evolutionary Genetics Analysis (MEGA) software version 4.0. Molecular Biology and Evolution, 24, 1596-1599. http://dx.doi.org/10.1093/molbev/msm092

Vandieken, V., Knoblauch, C., \& Jørgensen, B. B. (2006). Desulfotomaculum arcticum sp. nov., a novel spore-forming, moderately thermophilic, sulfatereducing bacterium isolated from a permanently cold fjord sediment of Svalbard. International Journal of Systematic and Evolutionary Microbiology, 56, 687-690. http://dx.doi.org/10.1099/ijs.0.64058-0

Vieira, R. P., Gonzalez, A. M., Cardoso, A. M., Oliveira, D. N., Albano, R. M., Clementino, M. M., et al. (2008). Relationships between bacterial diversity and environmental variables in a tropical marine environment, Rio de Janeiro. Environmental Microbiology, 10, 189-199. http://dx.doi.org/10.1111/j.1462-2920.2007.01443.x 
Wagner, A. O., Malin, C., \& Illmer, P. (2009). Application of Denaturing High-Performance Liquid Chromatography in Microbial Ecology: Fermentor Sludge, Compost, and Soil Community Profiling. Applied and Environmental Microbiology, 75, 956-964. http://dx.doi.org/10.1128/AEM.01411-08

Xiao, W., \& Oefner, P, J. (2001). Denaturing High-Perfomance Liquid Chromatography: A Review. Human Mutation, 17, 439-474. http://dx.doi.org/10.1002/humu.1130

Zhang, Y., Dong, J., Yang, Z., Zhang, S., \& Wang, Y. (2008). Phylogenetic diversity of nitrogen-fixing bacteria in mangrove sediments assessed by PCR-denaturing gradient gel $\begin{array}{lllll}\text { electrophoresis. } & \text { Archives } & \text { of } & \text { 19-28. }\end{array}$ http://dx.doi.org/10.1007/s00203-008-0359-5

Zhou, H. W., Wong, A. H. Y., Yu, R. M. K., Park, Y. D., Wong, Y. S., \& Tam, N. F. Y. (2009). Polycyclic Aromatic Hydrocarbon-Induced Structural Shift of Bacterial Communities in $\begin{array}{lllll}\text { Mangrove } & \text { Sediment. } & \text { Microbiology } & \text { Ecology, } & \text { 58, }\end{array}$ http://dx.doi.org/10.1007/s00248-008-9456-x

\section{Appendix}

Appendix 1. Taxonomic classification

\begin{tabular}{|c|c|c|c|c|c|c|}
\hline \multirow[t]{2}{*}{ Clone } & \multirow{2}{*}{$\begin{array}{l}\text { Sequence } \\
\text { Acession } \\
\text { no. }\end{array}$} & \multicolumn{5}{|c|}{ Closest relative } \\
\hline & & $\begin{array}{c}\text { Ident. } \\
(\%)\end{array}$ & $\begin{array}{l}\text { RDP Classifier } \\
\text { Phylum/Class/Order }\end{array}$ & Ident. (\%) & $\begin{array}{l}\text { BLAST-N } \\
\text { Identity }\end{array}$ & $\begin{array}{l}\text { Sequence } \\
\text { Acession no. }\end{array}$ \\
\hline \multirow[t]{3}{*}{ P1 Site HA23P4A4 } & HE648587 & 99 & Cyanobacteria & 99 & Uncultured cyanobacterium & JF344323 \\
\hline & & 99 & Cyanobacteria & & & \\
\hline & & 98 & Bacillariophyta & & & \\
\hline \multirow[t]{3}{*}{ HA23P6E7 } & HE648591 & 98 & Proteobacteria & 94 & Escherichia coli & JN180966 \\
\hline & & 89 & Gammaproteobacteria & & & \\
\hline & & 85 & Enterobacteriales & & & \\
\hline \multirow[t]{3}{*}{ HA23P7D10 } & HE648578 & 86 & Proteobacteria & 89 & Polynucleobacter necessarius & AB607317 \\
\hline & & 82 & Betaproteobacteria & & & \\
\hline & & 73 & Burkholderiales & & & \\
\hline \multirow[t]{3}{*}{$\mathrm{HA} 23 \mathrm{P} 4 \mathrm{C} 4$} & HE648594 & 94 & Proteobacteria & 91 & Uncultured betaproteobacterium & EU070245 \\
\hline & & 88 & Betaproteobacteria & & & \\
\hline & & 68 & Methylophilales & & & \\
\hline \multirow[t]{3}{*}{ SA21P11B1 } & HE648685 & 94 & Firmicutes & 95 & Uncultured Firmicutes bacterium & FJ490284 \\
\hline & & 71 & Bacilli & & & \\
\hline & & 71 & Bacillales & & & \\
\hline \multirow[t]{3}{*}{ SA21P11A1 } & HE648688 & 81 & Proteobacteria & 92 & Uncultured Desulfuromonas sp. & JF807003 \\
\hline & & 78 & Deltaproteobacteria & & & \\
\hline & & 61 & Desulfuromonadales & & & \\
\hline \multirow[t]{3}{*}{ SA21P11F1 } & HE648698 & 98 & Acidobacteria & 96 & Uncultured Acidobacteria bacterium & EF457339 \\
\hline & & 96 & Acidobacteria Gp18 & & & \\
\hline & & 96 & Gp18 & & & \\
\hline \multirow[t]{3}{*}{ SA21P7D10 } & HE651023 & 91 & Bacteroidetes & 85 & Uncultured Bacteroidetes bacterium & EF179856 \\
\hline & & 49 & Flavobacteria & & & \\
\hline & & 49 & Flavobacteriales & & & \\
\hline \multirow[t]{3}{*}{ SA21P10D10 } & HE648706 & 89 & Bacteroidetes & 85 & Uncultured Bacteroidetes bacterium & EF179857 \\
\hline & & 35 & Sphingobacteria & & & \\
\hline & & 35 & Sphingobacteriales & & & \\
\hline P2 Site & HE648600 & 100 & Proteobacteria & 100 & Polynucleobacter necessarius & AB607317 \\
\hline \multicolumn{7}{|l|}{ HA22P1A1 } \\
\hline & & 100 & Betaproteobacteria & & & \\
\hline & & 100 & Burkholderiales & & & \\
\hline
\end{tabular}




\begin{tabular}{|c|c|c|c|c|c|c|}
\hline \multirow[t]{2}{*}{ Clone } & \multirow{2}{*}{$\begin{array}{l}\text { Sequence } \\
\text { Acession } \\
\text { no. } \\
\end{array}$} & \multicolumn{5}{|c|}{ Closest relative } \\
\hline & & $\begin{array}{c}\text { Ident. } \\
(\%) \\
\end{array}$ & $\begin{array}{l}\text { RDP Classifier } \\
\text { Phylum/Class/Order }\end{array}$ & Ident. (\%) & $\begin{array}{l}\text { BLAST-N } \\
\text { Identity } \\
\end{array}$ & $\begin{array}{l}\text { Sequence } \\
\text { Acession no. }\end{array}$ \\
\hline \multirow[t]{3}{*}{ HА22Р6H3 } & HE648612 & 99 & Bacteroidetes & 95 & Arcicella sp. & JF700249 \\
\hline & & 96 & Sphingobacteria & & & \\
\hline & & 96 & Sphingobacteriales & & & \\
\hline \multirow[t]{3}{*}{ HA22P1D1 } & HE648614 & 100 & Proteobacteria & 95 & Bacteriovorax sp. & AY294222 \\
\hline & & 100 & Deltaproteobacteria & & & \\
\hline & & 100 & Bdellovibrionales & & & \\
\hline \multirow[t]{3}{*}{ HA22P3G2 } & HE648619 & 100 & Proteobacteria & 100 & Uncultured betaproteobacterium & EU070245 \\
\hline & & 100 & Betaproteobacteria & & & \\
\hline & & 100 & Methylophilales & & & \\
\hline \multirow[t]{3}{*}{ НА22Р5H2 } & HE648625 & 100 & Proteobacteria & 99 & Escherichia coli & JF910107 \\
\hline & & 100 & Gammaproteobacteria & & & \\
\hline & & 100 & Enterobacteriales & & & \\
\hline \multirow[t]{3}{*}{ HA22P8D4 } & HE648632 & 100 & Actinobacteria & 100 & Uncultured Propionibacterium sp. & FN554371 \\
\hline & & 100 & Actinobacteridae & & & \\
\hline & & 100 & Actinomycetales & & & \\
\hline \multirow[t]{3}{*}{ HA22P6E3 } & HE648641 & 100 & Proteobacteria & 100 & Uncultured alpha proteobacterium & GU734080 \\
\hline & & 100 & Alphaproteobacteria & & & \\
\hline & & 91 & Rhizobiales & & & \\
\hline \multirow[t]{3}{*}{ HA22P9G4 } & HE648643 & 99 & Acidobacteria & 96 & Uncultured Acidobacteriaceae bacterium & HM438160 \\
\hline & & 99 & Acidobacteria Gp6 & & & \\
\hline & & 99 & Gp6 & & & \\
\hline \multirow[t]{3}{*}{ HA22P7D6 } & HE648630 & 67 & Proteobacteria & 99 & Uncultured Cyanobacteria bacterium & CU920275 \\
\hline & & 65 & Deltaproteobacteria & & & \\
\hline & & 52 & Desulfuromonadales & & & \\
\hline \multirow[t]{3}{*}{ SA23P10B8 } & HE648715 & 100 & Proteobacteria & 98 & Uncultured Desulfuromonadales bacterium & JF727697 \\
\hline & & 100 & Deltaproteobacteria & & & \\
\hline & & 94 & Desulfobacterales & & & \\
\hline \multirow[t]{3}{*}{ SA23P6G1 } & HE648713 & 83 & Actinobacteria & 95 & Uncultured bacterium & JF320730 \\
\hline & & 42 & Coriobacteridae & & & \\
\hline & & 42 & Coriobacteriales & & & \\
\hline \multirow[t]{3}{*}{ SA23P11E8 } & HE648727 & 100 & Actinobacteria & 99 & Uncultured actinobacterium & EF135038 \\
\hline & & 100 & Actinobacteridae & & & \\
\hline & & 100 & Actinomycetales & & & \\
\hline \multirow[t]{3}{*}{ SA23P12B9 } & HE648719 & 95 & Acidobacteria & 92 & Uncultured Acidobacteria & GQ342374 \\
\hline & & 95 & Holophagae & & & \\
\hline & & 95 & Holophagales & & & \\
\hline \multirow[t]{3}{*}{ SA23P1F1 } & HE648721 & 100 & Proteobacteria & 99 & Thiobacillus prosperus & EU653291 \\
\hline & & 100 & Gammaproteobacteria & & & \\
\hline & & 85 & Chromatiales & & & \\
\hline \multirow[t]{3}{*}{ SA23P6D1 } & HE648726 & 99 & Firmicutes & 100 & Uncultured Streptococcus & FR690800 \\
\hline & & 98 & Bacilli & & & \\
\hline & & 92 & Bacillales & & & \\
\hline \multirow[t]{3}{*}{ SA23P1E1 } & HE648725 & 100 & Firmicutes & 100 & Uncultured Streptococcus & FR690800 \\
\hline & & 100 & Bacilli & & & \\
\hline & & 100 & Lactobacillales & & & \\
\hline SA23P8E7 & HE648731 & 100 & Acidobacteria & 99 & Uncultured Acidobacterium sp. & HQ730661 \\
\hline & & 100 & Acidobacteria Gp1 & & & \\
\hline & & 100 & Gp1 & & & \\
\hline $\mathrm{SA} 23 \mathrm{P} 2 \mathrm{~A} 4$ & HE648735 & 100 & Bacteroidetes & 100 & Uncultured bacterium & AB187890 \\
\hline & & 100 & Sphingobacteria & & & \\
\hline & & 100 & Sphingobacteriales & & & \\
\hline SA23P1B1 & HE648737 & 88 & Proteobacteria & 96 & Uncultured Sulfurospirillum sp. & EU628144 \\
\hline & & 82 & Epsilonproteobacteria & & & \\
\hline & & 81 & Campylobacterales & & & \\
\hline
\end{tabular}




\begin{tabular}{|c|c|c|c|c|c|c|}
\hline \multirow[t]{2}{*}{ Clone } & \multirow{2}{*}{$\begin{array}{l}\text { Sequence } \\
\text { Acession } \\
\text { no. }\end{array}$} & \multicolumn{5}{|c|}{ Closest relative } \\
\hline & & $\begin{array}{c}\text { Ident. } \\
(\%)\end{array}$ & $\begin{array}{l}\text { RDP Classifier } \\
\text { Phylum/Class/Order }\end{array}$ & Ident. (\%) & $\begin{array}{l}\text { BLAST-N } \\
\text { Identity }\end{array}$ & $\begin{array}{l}\text { Sequence } \\
\text { Acession no. }\end{array}$ \\
\hline \multirow[t]{3}{*}{ SA23P4E7 } & HE648740 & 83 & Chloroflexi & 97 & Uncultured Chloroflexi bacterium & GQ267091 \\
\hline & & 81 & Anaerolineae & & & \\
\hline & & 81 & Anaerolineales & & & \\
\hline \multirow{4}{*}{$\begin{array}{c}\text { P3 Site } \\
\text { HA21P2C1 }\end{array}$} & HE648644 & 100 & Proteobacteria & 100 & Uncultured beta proteobacterium & EU070245 \\
\hline & & & & & & \\
\hline & & 100 & Betaproteobacteria & & & \\
\hline & & 100 & Methylophilales & & & \\
\hline \multirow[t]{3}{*}{ HA21P4C1 } & HE648654 & 99 & Proteobacteria & 97 & Betaproteobacterium enrichment culture & HQ386537 \\
\hline & & 99 & Betaproteobacteria & & & \\
\hline & & 98 & Burkholderiales & & & \\
\hline \multirow[t]{3}{*}{ HA21P5H1 } & HE648668 & 99 & Proteobacteria & 98 & Uncultured betaproteobacterium & AB539996 \\
\hline & & 99 & Betaproteobacteria & & & \\
\hline & & 78 & Rhodocyclales & & & \\
\hline \multirow[t]{2}{*}{$\mathrm{HA} 21 \mathrm{P} 1 \mathrm{C} 1$} & HE648672 & 97 & TM7 & 98 & Uncultured bacterium & AB598999 \\
\hline & & 97 & TM7 & & & \\
\hline \multirow[t]{3}{*}{ HA21P5A1 } & HE648675 & 98 & Proteobacteria & 99 & Uncultured alphaproteobacterium & JN371341 \\
\hline & & 97 & Alphaproteobacteria & & & \\
\hline & & 96 & Rhodobacterales & & & \\
\hline \multirow[t]{3}{*}{ HA21P3G1 } & HE651022 & 100 & Actinobacteria & 100 & Uncultured Propionibacterium sp. & FN554371 \\
\hline & & 100 & Actinobacteridae & & & \\
\hline & & 100 & Actinomycetales & & & \\
\hline \multirow[t]{3}{*}{ HA21P7A1 } & HE648678 & 99 & Proteobacteria & 94 & Desulforhopalus singaporensis & NR_028742 \\
\hline & & 97 & Deltaproteobacteria & & & \\
\hline & & 88 & Desulfobacterales & & & \\
\hline \multirow[t]{3}{*}{$\mathrm{SA} 22 \mathrm{P} 4 \mathrm{~A} 12$} & HE648747 & 100 & Proteobacteria & 98 & Alishewanella sp. & GQ505294 \\
\hline & & 100 & Gammaproteobacteria & & & \\
\hline & & 94 & Alteromonadales & & & \\
\hline \multirow[t]{3}{*}{ SA22P4B11 } & HE648750 & 100 & Proteobacteria & 99 & Acinetobacter haemolyticus & HQ407291 \\
\hline & & 100 & Gammaproteobacteria & & & \\
\hline & & 100 & Pseudomonadales & & & \\
\hline \multirow[t]{3}{*}{ SA22P2D4 } & HE648754 & 95 & Proteobacteria & 96 & Uncultured bacterium & HQ434807 \\
\hline & & 95 & Deltaproteobacteria & & & \\
\hline & & 88 & Desulfuromonadales & & & \\
\hline \multirow[t]{3}{*}{ SA22P4D10 } & HE648762 & 100 & Firmicutes & 97 & Uncultured Firmicutes bacterium & FJ490284 \\
\hline & & 87 & Bacilli & & & \\
\hline & & 87 & Bacillales & & & \\
\hline \multirow[t]{3}{*}{ SA22P2H6 } & HE648766 & 87 & Spirochaetes & 92 & Uncultured Spirochaetes bacterium & GU236056 \\
\hline & & 87 & Spirochaetes & & & \\
\hline & & 87 & Spirochaetales & & & \\
\hline \multirow[t]{3}{*}{ SA22P2B6 } & HE648772 & 100 & Bacteroidetes & 98 & Enrichment culture bacterium & EU983257 \\
\hline & & 85 & Bacteroidetes_incertae_sedis & & & \\
\hline & & 85 & Prolixibacter & & & \\
\hline \multirow[t]{3}{*}{$\mathrm{SA} 22 \mathrm{P} 1 \mathrm{~A} 3$} & HE648792 & 100 & Proteobacteria & 97 & Bacterium Tol-K-1 & AB081545 \\
\hline & & 100 & Deltaproteobacteria & & & \\
\hline & & 92 & Syntrophobacterales & & & \\
\hline $\mathrm{SA} 22 \mathrm{P} 1 \mathrm{~F} 2$ & HE648796 & 100 & Firmicutes & 97 & Desulfotomaculum arcticum & NR_043579 \\
\hline & & 100 & Clostridia & & & \\
\hline & & 100 & Clostridiales & & & \\
\hline $\mathrm{SA} 22 \mathrm{P} 3 \mathrm{~B} 7$ & HE648814 & 90 & Bacteroidetes & 96 & Uncultured Bacteroidetes bacterium & $\mathrm{AB} 611170$ \\
\hline & & 51 & Flavobacteria & & & \\
\hline & & 51 & Flavobacteriales & & & \\
\hline SA22P3E9 & HE648793 & 100 & Bacteroidetes & 92 & Lactobacillales bacterium & AY581273 \\
\hline & & 47 & Bacteroidetes_incertae_sedis & & & \\
\hline & & 47 & Marinifilum & & & \\
\hline
\end{tabular}




\section{Macrothink}

Aquatic Science and Technology

ISSN 2168-9148 2013, Vol. 1, No. 1

Description: Analysis of the partial sequences of the 16S rRNA gene obtained from the peaks generated by the DHPLC for the different sites in Salina Lake, and their tentative taxonomic classification, using two database (RDP and NCBI).

Appendix 2. Libshuff analyses comparison

\begin{tabular}{ccc}
\hline Comparison & dCXY Score & Significance \\
\hline Sedimento (P1-P2) & 0.00159181 & 0.7297 \\
Sedimento (P2-P1) & 0.04112548 & $<0.0001$ \\
Sedimento (P1-P3) & 0.00462641 & 0.6398 \\
Sedimento (P3-P1) & 0.04291301 & $<0.0001$ \\
Sedimento (P2-P3) & 0.01496923 & 0.0067 \\
Sedimento (P3-P2) & 0.06626945 & $<0.0001$ \\
Água (P1-P2) & 0.00318128 & 0.3662 \\
Água (P2-P1) & 0.15063480 & $<0.0001$ \\
Água (P1-P3) & 0.49854240 & $<0.0001$ \\
Água (P3-P1) & 0.50566340 & $<0.0001$ \\
Água (P2-P3) & 0.95203501 & $<0.0001$ \\
Água (P3-P2) & 0.65223309 & $<0.0001$ \\
P1 (Água - Sedimento) & 0.02212464 & $<0.0001$ \\
P1 (Sedimento- Água) & 0.02664804 & $<0.0001$ \\
P2 (Água - Sedimento) & 0.10018914 & $<0.0001$ \\
P2 (Sedimento - Água) & 0.03510955 & $<0.0001$ \\
P3 (Água - Sedimento) & 0.65223309 & $<0.0001$ \\
P3 (Sedimento - Água) & 0.89750832 & $<0.0001$ \\
\hline
\end{tabular}

Description: Results of the Libshuff analyses comparing the libraries for the water and sediment samples from the three sampling sites (P1, P2, P3).

\section{Copyright Disclaimer}

Copyright reserved by the author(s).

This article is an open-access article distributed under the terms and conditions of the Creative Commons Attribution license (http://creativecommons.org/licenses/by/3.0/). 